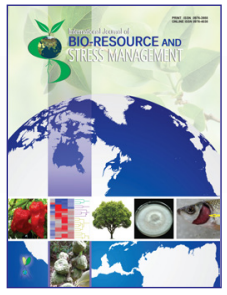

\title{
A Meta-Analysis of the Literature on Agricultural Innovation
}

\author{
Haridra Sharma*
}

Dept. of Extension Education, FA, Assam Agricultural University, Jorhat, Assam (785 013), India

\section{Open Access}

Corresponding Author

Haridra Sharma

e-mail: hsarma08511@rediffmail.com

Citation: Sharma, 2019. A Meta-Analysis of the Literature on Agricultural Innovation. International Journal of Bio-resource and Stress Management 2019, 10(4):368-376. HTTPS://DOI.ORG/10.23910/ IJBSM/2019.10.4.2010

Copyright: (c) 2019 Sharma. This is an open access article that permits unrestricted use, distribution and reproduction in any medium after the author(s) and source are credited.

Data Availability Statement: Legal restrictions are imposed on the public sharing of raw data. However, authors have full right to transfer or share the data in raw form upon request subject to either meeting the conditions of the original consents and the original research study. Further, access of data needs to meet whether the user complies with the ethical and legal obligations as data controllers to allow for secondary use of the data outside of the original study.

Conflict of interests: The authors have declared that no conflict of interest exists.

Article History

RECEIVED in $02^{\text {nd }}$ July 2019 RECEIVED in revised form $19^{\text {th }}$ August 2019 ACCEPTED in final form $30^{\text {th }}$ August 2019

\begin{abstract}
Agricultural technologies are being innovated and evaluated to assess its impact on agriculture. The findings of such evaluative studies are being published in different forums for the benefit of mankind. As such, a huge literature has emerged in recent years revealing different methodologies and approaches of evaluation. The purpose of the present study is to find out ways the innovations in agriculture are being evaluated, through a meta-analysis of 25 systematically selected articles. The specific objectives are to identify the variables explaining agricultural innovation and to analyze the relationship among those variables. The results revealed that majority of the literature discussed the innovation with prime purpose - 'environment protection (60\%)', followed by 'improving farm performance $(28 \%)^{\prime}$. The main agricultural innovations studied by researchers are those processes which involve the 'environment preserving technologies (36\%)' and 'precision technologies (20\%)'. Evaluation indicators such as the ability to 'reducing environmental impact (32\%)' and 'strengthening farmer's participation $(32 \%)$ ' were studies in most of the cases. In terms of innovation strategies, both proactive $(44 \%)$ and reactive $(48 \%)$ approach were found almost equally. On analysing the relationship between the identified categorical variables, it came to the knowledge that studies focusing on environment protection as prime purpose included the analysis of innovation processes related to environment preserving and precision technologies that are capable of reducing environmental impact through strengthening farmer's participation and are proactive in nature.
\end{abstract}

Keywords: Agriculture, evaluation, innovation, literature, meta-analysis

\section{Introduction}

Agriculture today is much more than a primary occupation. Stakeholders of agriculture are trying to produce food and other basic commodities needed for a population more than seven billion on the earth. By 2025, world population will cross the 8 billion mark and with the increasing population the need for food and other basic commodities will further increase. To sustainably meet the increasing demand for food, the science of agriculture need to be more innovative and dynamic. Referring to India, with 1.21 billion populations (2011 census), India is expecting to overtake China as the world's most populous country by 2030 . India is the second fastest growing economy in the world and has the world's second largest arable land base with 157.35 million hectares after the United States (The Helgi Library, 2014). While, agriculture continues to be the primary source of livelihood for about $58 \%$ of India's population, most of the farmers are lacking technical knowledge which must be remedied 
by realistic technical assistance (Khan, 2011). Further, where Indian economy is progressing, the share of agriculture to the total economy is declining and so as its ability to support the farmers. As per the Report of the Committee on Doubling Farmers' Income, 2017, the average monthly income of an agricultural household during July 2012 to June 2013 was as low as ₹ 6,426/- as against its average monthly consumption expenditure of ₹ 6, 223/-.

India needs sustainable agrarian growth and development. Aiming for sustainability with a definite roadmap is certainly a good option for India where land holdings are small and farmers are resource poor (Pawar, 2010). The strategies for sustainable development depend up on innovating situation specific technologies and promotion of those innovations. Innovation is needed to answer the risks and uncertainties associated with agriculture. In the era of knowledge-based economy, innovation plays an important role in order to improve competitiveness and strengthen social cohesion of the nation (Putri et al., 2015).

Though enormous researches have been undertaken, the results of which are published in reputed journals on various aspects with special reference to the mechanism of resistance to the stresses in agriculture and their management, but insignificant progress has been attained for their practical utility in the farmer's fields (Maiti, 2012). It may be due to fact that such literature is rarely referred for policy formulation and decision making. Such literature can provide important information base for decision making and evidence base for adapting agrarian policy decisions to the present socio-economic realities. Therefore, there is a need to analyse those literature to comprehend the trend and compare innovation in agriculture to augment policy decisions.

To the knowledge of the author, very few works have been done on quantitative analyse of those literature focusing on agricultural innovation. Keeping this in view, the present study has been designed to review the literature on agricultural innovation and highlight the findings through meta- analysis. The general objective of the study is to conduct a quantitative analysis of the innovation literature with specific objectives to (i) identify the variables explaining agricultural innovation that are found in literature in recent years and (ii) analyse the relationship among those variables.

\section{Materials and Methods}

The study was conducted during August to October 2018 to identify the literature available in the internet for the period January 2014 to June 2018. Steps followed were:

1. Analysis of the present context of agriculture

2. Identification of area of interest

3. Determination of level of analysis

4. Choosing online international database

5. Selection of article on phases

\section{Grouping of concepts based on theme \\ 7. Coding \\ 8. Data analysis}

Literature on agricultural innovation were reviewed and meta-analysed for getting an overview of the present scenario of the world of innovation in agriculture.

\subsection{Meta-analysis}

Meta-analysis is a statistical analysis that combines the results of multiple scientific studies with same objective for investigation. Gene V Glass (1976) coined the term 'meta-analysis' to refer to 'the statistical analysis of a large collection of analysis results from individual studies for the purpose of integrating the findings'. Meta-analysis has the capacity to eliminate human errors i.e. sampling error, error of measurement and range variation and thereafter cumulates the results across studies. It refers to the statistical methods of combining evidence, leaving other aspects of 'research synthesis' or 'evidence synthesis', such as combining information from qualitative studies, for the more general context of systematic reviews (Glossary at Cochrane Collaboration).

\subsection{Selection of online international database}

The international database "ScienceDirect" (https:// www.sciencedirect.com) was selected purposively. Key words "innovation", "agriculture", "evaluation", "asses" in different combinations was put in the "advance search" field for reference identification.

For identification and selection of the article, Preferred Reporting Items for Systematic Reviews and Meta-Analyses (PRISMA) was followed. PRISMA is an evidence-based minimum set of items aimed at helping researcher to report a wide array of systematic reviews and meta-analyses them (Anonymous). PRISMA focuses on ways in which researcher can ensure a transparent and complete reporting of similar type of research. The aim of the PRISMA Statement is to help authors improve the reporting of systematic reviews and meta-analyses (Liberati et al., 2009).

\subsection{Identification of groups for coding concepts}

The group for identifying and analysing the concepts were established. The method followed for the present study was adapted to the studies conducted by Brunette et al. (2018) and Oana COCA (2017). Brunette et al. (2018) conducted meta-analysis of literature to study the adaptation to climate change in forestry using the statistical technique- Multiple Correspondence Analysis (MCA). While Oana COCA (2017) applied MCA to evaluate innovation in agriculture through meta-analysis of literature from 1990 to 2016.

\subsection{Identification of concepts and coding}

The content of the articles were analysed and coding was done based on the grounded theory.

\subsection{Data analysis}

After identification of the qualitative variables that regularly 
define agricultural innovation, Multiple Correspondence Analysis (MCA) was done to analyse the relationship between qualitative variables. Application of MCA is justified as the dataset of the study consists solely of non-linear categorical variables with more than 2 modalities.

MCA is a multivariate technique designed to discover both inter-relations and intra-relations of two or more categorical variables by reviewing the closeness and remoteness between the variables (Anderson, 1990; Devillers and Karcher, 1991; Chou, 1994; Greenacre, 1998; Baspinar and Mendes, 2002; Mendes, 2002). Dots being close to each other are commented to be similar to or related with each other depending on the areas they fall into. Similarly, dots being far from each other are commented to be unrelated (Dunteman, 1989).

\section{Results and Discussion}

The results of the study are presented under the following heads :

\subsection{Identification and selection of reference}

By following the steps (Table 1 and 2) references were identified and selected:

Table 1: Article selection in the first and second phase

\begin{tabular}{lllcc}
\hline Phase & Items & $\begin{array}{c}\text { No. of article } \\
\text { displayed }\end{array}$ & No. of article rejected & $\begin{array}{c}\text { No. of article selected for } \\
\text { the next step }\end{array}$ \\
\hline $\begin{array}{l}\text { Phase-I: Identi- } \\
\text { fication }\end{array}$ & $\begin{array}{l}\text { Total article displayed } \\
\text { Article considered with } \\
\text { criteria “Research article }\end{array}$ & 994 nos. & 302 nos. rejected from 1296 nos. & 1296 nos. \\
& Article in open access & 148 nos. & 846 nos. rejected from 994 nos. & 148 nos. \\
$\begin{array}{l}\text { Phase-II: } \\
\text { Screening }\end{array}$ & $\begin{array}{l}\text { For the year January } \\
\text { 2014- June 2018 }\end{array}$ & 115 nos. & 33 nos. rejected from 148 nos. & 115 nos. \\
\hline
\end{tabular}

Table 2: Article excluded in third phase

\begin{tabular}{llll}
\hline Phase & Excluding criteria & $\begin{array}{l}\text { No. of article } \\
\text { rejected }\end{array}$ & No. of article selected \\
\hline $\begin{array}{l}\text { Phase-III: Exclu- } \\
\text { sion \& Inclusion }\end{array}$ & $\begin{array}{l}\text { Were not available in full } \\
\text { paper }\end{array}$ & 1 nos. & Out of 115 nos. of articles, 114 nos. considered for next step \\
& $\begin{array}{lll}\text { Were not written in English } \\
\text { Excluded by title }\end{array}$ & 4 nos. & Out of 114 nos. of articles, 110 nos. considered for next step \\
& 30 nos. & Out of 110 nos. of articles, 80 nos. considered for next step \\
& 33 nos. & Out of 80 nos. of articles, 47 nos. considered for next step
\end{tabular}

In the third phase, 115 numbers of articles were further verified and irrelevant articles were removed based on the following criteria (Table 2). Thus, a total of 25 articles were selected for further analysis (Table 3).

3.1. The selected articles are described on the following criteria

\subsubsection{Methodology used}

According to the methodology used (Figure 1), articles are classified broadly in four categories: case study, survey, review and other articles. Majority of the studies evaluated innovations as detailed case studies (31\%). In the other category (30\%), innovations were found to be evaluated through experiments, in-vivo experiments and action research.

\subsubsection{Distribution based on Continent}

Frequency distribution of articles (Figure 2) based on place of reporting and evaluation of innovation has shown that as high as $36 \%$ of the total articles were published from Asian countries followed by $24 \%$ from European countries.
3.2. Identification of variables explaining agricultural innovation

\subsubsection{Identification of groups for coding concepts}

The group for identifying and analysing the concepts were established and presented in Table 4.

\subsubsection{Identification of concepts and coding}

For analysis of each group, key phrases describing same phenomenon were categorised in some concepts. Thus, a total of 19 sub groups (concepts) were identified and grouped in 4 main groups (construct). Now the concept "agricultural innovation" can viewed having 19 dimensions. All the concepts were coded using numbers from 1 to 19 (Table 5).

\subsubsection{Frequency and percentage analysis of the key concepts}

The frequency and percentage distribution of literature according to the key concepts were identified and tabulated (Table 5) for further analysis. It is to mention that where there was more than one purpose, type or evaluation indicator present in a given paper, it was decided to consider the 


\begin{tabular}{|c|c|c|c|c|}
\hline SI. No. & Author & Place & Innovations & Methodology \\
\hline 1. & Knuth et al. (2018) & Germany & Farm management systems (FMS) & Survey \\
\hline 2. & Mchunu et al. (2018) & South Africa & Aquaponic system & Survey \\
\hline 3. & Dayamba et al. (2018) & West Africa & $\begin{array}{l}\text { Participatory Integrated Climate Services for Agri- } \\
\text { culture (PICSA) }\end{array}$ & Survey \\
\hline 4. & Masseroni et al. (2018) & Europe & Automatic system for paddyirrigation & Case study \\
\hline 5. & Rose et al. (2018) & UK & Decision support tools & Case study \\
\hline 6. & Bruce and Spinardi (2018) & UK & Resource efficient technologies & Case study \\
\hline 7. & Sixt et al. (2018) & Jordan & Water conserving agricultural practice & Case study \\
\hline 8. & Toop et al. (2017) & Europe & Circular Economy (AgroCycle) & Experiment \\
\hline 9. & Deng et al. (2017) & China & Cropping system innovation & Review \\
\hline 10. & Kanama and Nakazawa (2017) & Japan & Ingredient-branded foods (IBFs) & Case study \\
\hline 11. & $\begin{array}{l}\text { Samiee and Rezaei-Moghad- } \\
\text { dam (2017) }\end{array}$ & Iran & No-till technology & Survey \\
\hline 12. & Cid et al. (2016) & Brazil & $\begin{array}{l}\text { Application of Fipronil in an injectable form (sub- } \\
\text { cutaneously) }\end{array}$ & $\begin{array}{l}\text { In vivo experi- } \\
\text { ment }\end{array}$ \\
\hline 13. & Phondani et al. (2016) & India & Propagation protocols of 11 selected maps & Experiment \\
\hline 14. & Murage et al. (2015) & $\begin{array}{l}\text { Eastern } \\
\text { Africa }\end{array}$ & Climate-smart push-pull technology & Survey \\
\hline 15. & Haque et al. (2015) & Bangladesh & $\begin{array}{l}\text { Integrated floating cage aquageoponics system } \\
\text { (IFCAS) }\end{array}$ & $\begin{array}{l}\text { Action } \\
\text { research }\end{array}$ \\
\hline 16. & Vahid et al. (2015) & Canada & $\begin{array}{l}\text { A hot water Selected Inverted Sink (SIS) hybrid } \\
\text { system (HWSH) }\end{array}$ & $\begin{array}{l}\text { Field cam- } \\
\text { paigns }\end{array}$ \\
\hline 17. & Boden et al. (2015) & Scotland & Scenario planning methodologies & Review \\
\hline 18. & Zhang and Yan (2014) & China & Photovoltaic water pumping systems & Experiment \\
\hline 19. & Solh and Ginkel (2014) & $\begin{array}{l}\text { Lebanon, } \\
\text { Western Asia }\end{array}$ & Integrated agro-ecosystem approach & Review \\
\hline 20. & Islam and Reeder (2014) & US & No-till (NT) farming & Case study \\
\hline 21. & Awada et al. (2014) & Canada & Zero tillage (ZT) & Review \\
\hline 22. & Hill et al. (2014) & Canada & $\begin{array}{l}\text { Invitational Drought Tournament (IDT), a simulation } \\
\text { adaptation framework }\end{array}$ & \\
\hline 23. & Freitas and Landers (2014) & Brazil & Zero tillage conservation agriculture (ZT/CA) & Case study \\
\hline 24. & $\begin{array}{l}\text { Ramchandani and Karmarkar } \\
\text { (2014) }\end{array}$ & India & $\begin{array}{l}\text { System and action-based research consortium for } \\
\text { improvement in livelihood }\end{array}$ & Case study \\
\hline 25. & $\begin{array}{l}\text { Bellotti and Rochecouste } \\
\text { (2014) }\end{array}$ & Australia & Conservation agriculture & Case study \\
\hline
\end{tabular}

principal one for the present study.

Analysis of the literature reveals that main objective of agricultural innovation in recent years is to ensure environmental protection (60\%), followed by improving farm performance ( $28 \%$ ).

Majority of the researchers have discussed process innovation (92\%) in their research findings. Among the process innovation, most frequently studied are the environment preserving technologies (36\%) and precision technologies (20\%). Process innovation related to computerization of agriculture and crop organization studied by $16 \%$ each. Innovations for manufacturing and processing is discussed in only $4 \%$ of the articles. While, $8 \%$ of total articles have evaluated product innovation. 


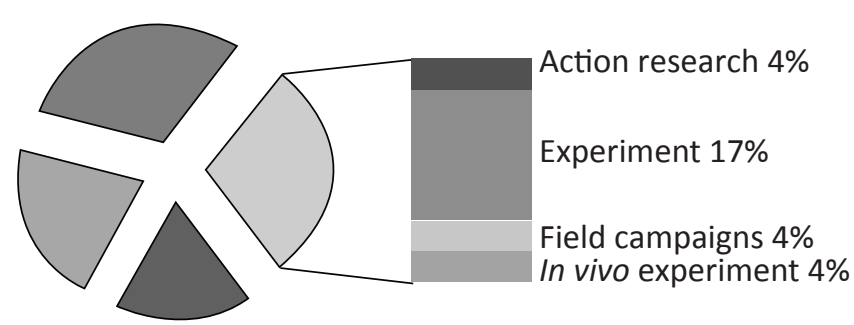

Figure 1 : Articles distribution based on methodology

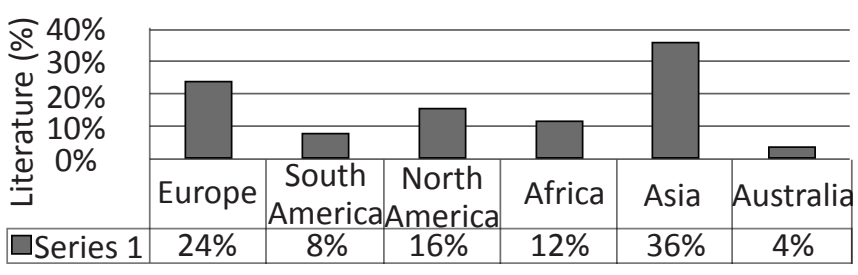

Figure 2: Article distribution based on Continent

\begin{tabular}{lcl}
\hline Table 4: Major groups for concept categorization \\
\hline Group & Symbol & Group details \\
\hline $\begin{array}{l}\text { Innovation pur- } \\
\text { pose }\end{array}$ & Ol & $\begin{array}{l}\text { The prime objective for in- } \\
\text { novation in agriculture } \\
\text { Type -Process }\end{array}$ \\
$\begin{array}{l}\text { Innovation } \\
\begin{array}{l}\text { Type - Product } \\
\text { innovation }\end{array}\end{array}$ & TPss & $\begin{array}{l}\text { can be regarded as process } \\
\text { Innovations in agriculture that } \\
\text { can be regarded as product } \\
\text { Evaluation cri- } \\
\text { teria }\end{array}$ \\
$\begin{array}{l}\text { Innovation strat- } \\
\text { egy }\end{array}$ & IA & $\begin{array}{l}\text { Criteria through which in- } \\
\text { novation has been assessed } \\
\text { Approach taken for innovation }\end{array}$ \\
\hline
\end{tabular}

Evolution indicators was operationalised as the criteria based on which the innovation has been evaluated by the researchers. Majority of the studies measured the innovation in terms of the ability to reduce environmental impact (32\%) and to strengthen farmers' participation (32\%) in innovation development, transfer, diffusion and adaptation to the local system. Innovation evaluation criteria represented by lowering cost and copyright protection has the lowest share with only $4 \%$.

As per analysis of the articles, it is clear that majority of the innovations are process innovations. And for process innovation, obtaining copy right may not considered as important by the innovators. Again lowering cost may not considered as prime criteria for evaluation while aiming at environmental protection and improving farm performance, which needs long term interventions. The cost may be equated with higher profit with accelerated scale of economy.

While the innovation strategies - proactive and reactive were found to be adopted equally (approx.) with 44 and $48 \%$, respectively. Literature that discussed the innovation adopting a Business-as-usual strategy is only $2 \%$.

\subsection{Relationship between qualitative variables}

In the last phase of coding, based on the prime purpose

\begin{tabular}{|c|c|c|c|}
\hline Groups & Concepts groups & Code & $\begin{array}{c}\text { Articles where } \\
\text { concept has } \\
\text { been found } \\
\text { frequency } \\
\text { (Percentage) }\end{array}$ \\
\hline \multirow[t]{4}{*}{$\begin{array}{l}\text { Innovation } \\
\text { purpose }\end{array}$} & $\begin{array}{l}\text { Environment pro- } \\
\text { tection }\end{array}$ & OI1 & $15(60)$ \\
\hline & $\begin{array}{l}\text { Consumer protec- } \\
\text { tion }\end{array}$ & $\mathrm{OI2}$ & $2(8)$ \\
\hline & $\begin{array}{l}\text { Resource manage- } \\
\text { ment }\end{array}$ & OI3 & 1(4) \\
\hline & $\begin{array}{l}\text { Improving farm } \\
\text { performance }\end{array}$ & $\mathrm{OI4}$ & $7(28)$ \\
\hline \multirow{5}{*}{$\begin{array}{l}\text { Type -Pro- } \\
\text { cess inno- } \\
\text { vation }\end{array}$} & $\begin{array}{l}\text { Manufacturing } \\
\text { and processing }\end{array}$ & TPss5 & 1(4) \\
\hline & $\begin{array}{l}\text { Environment pre- } \\
\text { serving technolo- } \\
\text { gies }\end{array}$ & TPss6 & $9(36)$ \\
\hline & $\begin{array}{l}\text { Precision technol- } \\
\text { ogies }\end{array}$ & TPss7 & $5(20)$ \\
\hline & Crop organization & TPss8 & $4(16)$ \\
\hline & $\begin{array}{l}\text { Computerization } \\
\text { of technology }\end{array}$ & TPss9 & $4(16)$ \\
\hline $\begin{array}{l}\text { Type - Prod- } \\
\text { uct innova- } \\
\text { tion }\end{array}$ & Input innovation & TPct10 & $2(8)$ \\
\hline \multirow{6}{*}{$\begin{array}{l}\text { Evaluation } \\
\text { Indicator }\end{array}$} & Lowering costs & EC11 & $1(4)$ \\
\hline & Production growth & EC12 & $3(12)$ \\
\hline & $\begin{array}{l}\text { Reducing environ- } \\
\text { mental impact }\end{array}$ & $\mathrm{EC} 13$ & $8(32)$ \\
\hline & $\begin{array}{l}\text { Strengthening } \\
\text { farmers participa- } \\
\text { tion }\end{array}$ & EC14 & $8(32)$ \\
\hline & Revenue growth & EC15 & $4(16)$ \\
\hline & $\begin{array}{l}\text { Copyright protec- } \\
\text { tion }\end{array}$ & EC16 & $1(4)$ \\
\hline \multirow{3}{*}{$\begin{array}{l}\text { Innovation } \\
\text { Strategy }\end{array}$} & Proactive & IA17 & $11(44)$ \\
\hline & Reactive & IA18 & $12(48)$ \\
\hline & $\begin{array}{l}\text { Business-as-usual } \\
\text { (BAU) }\end{array}$ & IA19 & $2(8)$ \\
\hline
\end{tabular}

of the innovation, further grouping was done. Innovations focusing on environment protection was grouped as ' $A$ ' and not focusing on environment protection was grouped as ' $B$ '. Then, the relationship of this major variable with the other variables was analysed through Multiple Correspondence Analysis (MCA).

As the first step of MCA technique, Matrix I (indicator matrix) 
was created by taking the total variables with respective levels in columns and test units in rows. Therefore, Matrix I of this study consists of 19 columns $(4+5+1+6+3=19)$ and 25 rows. Matrix I was created by assigning code ' 1 ' for the levels of the categorical variable containing the test units, and code ' $O$ ' not containing the test units. In this study, Matrix I was analysed by means of the Burt matrix consisting of internal multiplies of Matrix I. The results of the MCA analysis are presented in Figure 3 . The analysis in question was conducted by using the XLSTAT software.

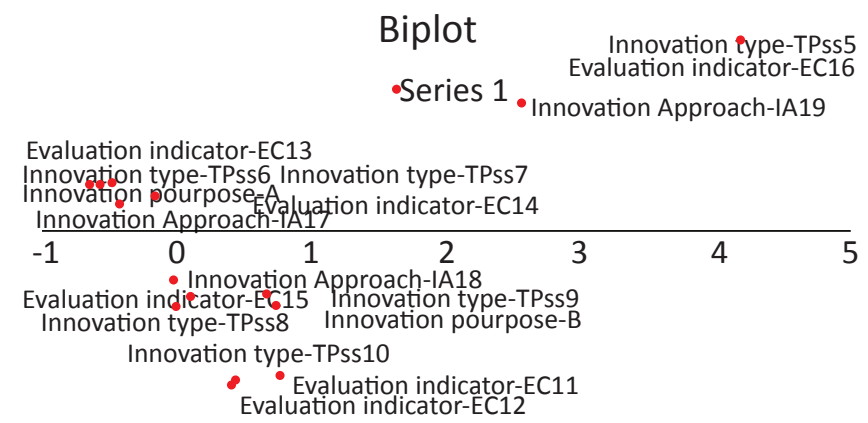

Figure 3: Diagrammatic presentation of MCA results on agricultural innovation
To reflect the consistency of the test, the Cronbach's alpha reliability coefficient should be as close to 1 , with a minimum limit of 0.7 for considering as consistent for most research. For the present study, the Cronbach's alpha reliability coefficient has a value of 0.768 , which indicates consistency and relevance of the test.

Total inertia is 3.25 (Table 6). Main use of the inertia is that it acts as an indicator of the numbers of axes to retain for further analysis. From the results of MCA, it was seen that the Scree plot has shown an elbow on the third dimension. So the first and second dimensions are considered for the further analysis.

The two factorial axes explain $39 \%$ of the total variance, and the first factorial axis explains $21 \%$ of variance, indicating the fact that there is no much difference in the two axes.

Hence, studies focusing on environment protection as prime purpose (Figure 3 ) included the analysis of innovation processes related to environment preserving and precision technologies that are capable of reducing environmental impact through strengthening farmer's participation and are proactive in nature.

Both the innovation processes related to protect environment

Table 6: Eigenvalues from MCA

\begin{tabular}{lcccccccccccc}
\hline Dimensions & $\mathrm{F}_{1}$ & $\mathrm{~F}_{2}$ & $\mathrm{~F}_{3}$ & $\mathrm{~F}_{4}$ & $\mathrm{~F}_{5}$ & $\mathrm{~F}_{6}$ & $\mathrm{~F}_{7}$ & $\mathrm{~F}_{8}$ & $\mathrm{~F}_{9}$ & $\mathrm{~F}_{10}$ & $\mathrm{~F}_{11}$ & $\mathrm{~F}_{12}$ \\
\hline Eigenvalue & 0.70 & 0.57 & 0.42 & 0.37 & 0.34 & 0.23 & 0.20 & 0.16 & 0.10 & 0.09 & 0.06 & 0.02 \\
Variability (\%) & 21.42 & 17.60 & 12.79 & 11.26 & 10.52 & 7.17 & 6.02 & 5.07 & 2.97 & 2.75 & 1.70 & 0.74 \\
Cumulative \% & 21.42 & 39.01 & 51.80 & 63.06 & 73.58 & 80.75 & 86.77 & 91.84 & 94.81 & 97.57 & 99.26 & 100.00 \\
\hline
\end{tabular}

and precision farming, indicated the need for a participatory approach. Based on Rogers (1960), precision crop production as an agricultural innovation is less compatible, as farmers greatly vary in knowledge, skills and attitude to innovations, as well as in farm size and financial funds. It may also due to lack of counselling support. Much importance has been, therefore, given on involving farmers for social learning, community decision making and socialization of the precision farming technologies (Dayamba et al., 2018; Boden et al., 2015; Hill et al., 2014; Freitas and Landers, 2014; Bellotti and Rochecouste, 2014)

Studies not focusing on environment protection as prime purpose are found to evaluate innovations related to crop organization and computerization of agriculture resulted in revenue growth and were mostly reactive.

One more finding emerged from this study based on innovation strategy adopted. Findings showed that innovations reported from developed countries are more proactive (32\%) in their approach compared to developing countries reporting only $12 \%$ proactive innovations (Figure 4).

While reviewed on the basis of prime purpose of innovation (Figure 5), more than half of the articles focusing on environment protection were published from developed countries (53.33\%), out of which, $40 \%$ were proactive

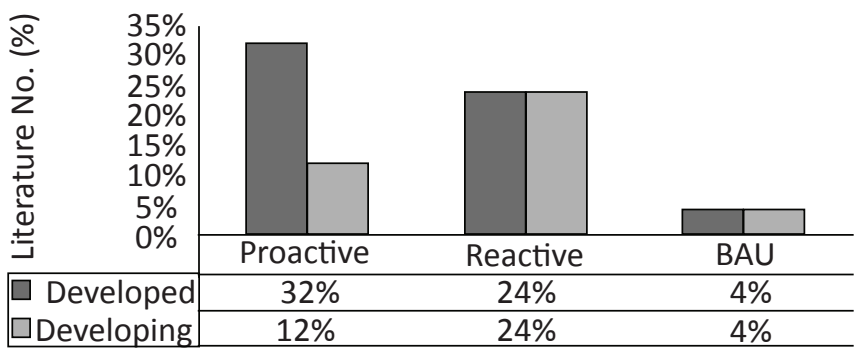

Figure 4: Distribution based on Innovation strategy

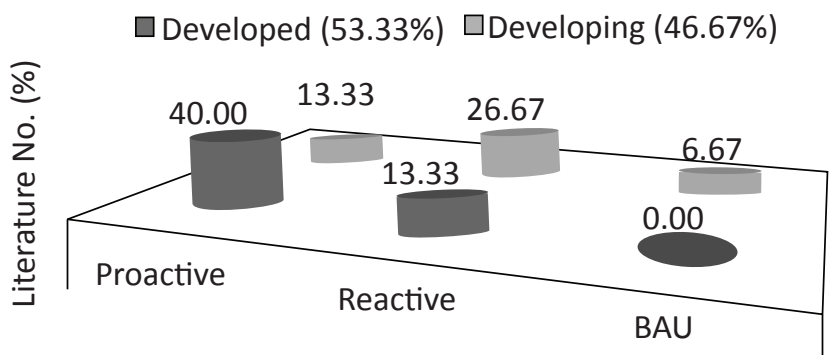

Figure 5: Distribution of innovation purpose environment protection based on strategy

innovations. Compared to $46.67 \%$ articles focusing on environment protection reported from developing countries were mainly reactive $(26.67 \%)$ in their approach. Less reporting of agricultural innovations for protecting environment and 
cope with changing environment from developing countries may be due to the fact that there is less intervention in the said direction, whereas the developing world is more vulnerable and affected by adverse climatic factors. Further, future of agriculture and rural poverty alleviation depends on how we ensure food, nutrition and livelihood security through sustainable and integrated family farming, which is resilient to uncertainties of open markets and climatic variability (Dasgupta et al., 2015).

It can be infer that innovation strategies, given the less availability of literature on environment protection, would tend to be reactive than proactive (Brunette et al., 2018). The observation is in line with the findings of Pasgaard \& Strange (2013) indicating "the supply of climate-change knowledge is biased towards richer countries, which are more stable and less corrupt, have higher school enrolment and expenditure on research and development, emit more carbon and are less vulnerable to climate change."

\section{Conclusion}

Innovation is essential to enhance the value of agriculture. In the changing scenario proactive strategies need to be adopted during technology innovation and dissemination. Extension Specialists has to adopt strategies for knowledge negotiation, moderator in decision making, project evaluator, programming of farm input and budget, facilitating simulation exercises, forecasting technology, demand articulation etc., beside dissemination of technology. A proactive strategy is expected to generate demand-driven and location-specific technologies with strengthen knowledge base of the farmers for sustainable livelihood.

\section{Future Lines of Research}

Skills needed by the young social scientists and extension specialists to face the diversified challenges of $21^{\text {st }}$ century Indian agriculture through further meta-analysis of literature.

\section{References}

Anderson, E.B., 1990. The Statistical Analysis of Categorical Data. Heidelberg, New York, USA, 363-405.

Awada, L., Lindwall, C.W., Sonntag, B., 2014. The development and adoption of conservation tillage systems on the Canadian Prairies. International Soil and Water Conservation Research 2(1), 47-65. Available online at www.sciencedirect.com.

Baspinar, E., Mendes, M., 2000. Iki Yonlu Tablolarda Uyum Analizi Tekniginin Kullanimi, (The Usage of Correspondence Analysis Technique at the Contingency Tables) A.U.Z.F. Tarim Bilimleri Dergisi. Ankara. 6 (2),98106,

Bellotti, B., Rochecouste, J.F., 2014. The development of Conservation Agriculture in Australia-Farmers as innovators. International Soil and Water Conservation
Research 2(1), 21-34. Available online at www. sciencedirect.com.

Boden, L.A., Auty, H., Bessell, P., Duckett, D., Liu, J., Kyle, C., McKee, A., Sutherland, L., Reynolds, J., Bronsvoort, B.M., McKendrick, I.J., 2015. Scenario planning: The future of the cattle and sheep industries in Scotland and their resiliency to disease. Preventive Veterinary Medicine 121, 353-364. Available online at www.sciencedirect. com.

Bruce, A., Spinardi, G., 2018. On a wing and hot air: Ecomodernisation, epistemic lock-in, and the barriers to greening aviation and ruminant farming. Energy Research \& Social Science 40, 36-44. Available online at www.sciencedirect.com.

Brunette, M., Bourke, R., Hanewinkel, M., Yousefpour, R.,2018. Adaptation to Climate Change in Forestry: A Multiple Correspondence Analysis(MCA). Forests, 9(20). www.mdpi.com/journal/forests

Chou, R.J., 1994. Multivariate Analysis and Its Application,USA, 194-210.

Cid, Y.P., Ferreira, T.P., Magalhaes, V.S., Correia, T.R., Scott, F.B., 2016. Injectable fipronil for cattle: Plasma disposition and efficacy against Rhipicephalus microplus. Veterinary Parasitology . 220, 4-8. Available online at www.sciencedirect.com.

Dasgupta, P., Goswami, R., Ali, N., Chakraborty, S., Saha, S.K., 2015. Multifunctional Role of Integrated Farming System in Developing Countries. International Journal of Bio-resource and Stress Management 6(3), 424-432. Available online at www.pphouse.org . DOI:10.5958/0976-4038.2015.00057.3

Dayamba, D.S., Ky-Dembele, C., Bayala, J., Dorward, P., Clarkson, G., Sanogo, D., Mamadou, L.D., Traoré, I., Diakité, A., Nenkam, A., Binam, J.N., Ouedraogo, M., Zougmore, R., 2018. Assessment of the use of Participatory Integrated Climate Services for Agriculture (PICSA) approach by farmers to manage climate risk in Mali and Senegal. Climate Services. https://doi. org/10.1016/j.cliser.2018.07.003. Available online at www.sciencedirect.com.

Deng, A., Chen, C., Feng, J., Chen, J., Zhang, W., 2017.Cropping system innovation for coping with climatic warming in China. The Crop Journal 5,136-150. Available online at www.sciencedirect.com.

Devillers, J., Karcher, W., 1991. Applied Multivariate Analysis in SAR and Environmental Studies. Dordrecht, Netherlands, 1-32.

Dunteman, G.H., 1989. Principal Components Analysis, Sage Publication, Inc. California, USA, 96.

Freitas, P.L. de, Landers, J.N., 2014. The transformation of agriculture in Brazil through development and adoption of Zero Tillage Conservation Agriculture. International Soil and Water Conservation Research 2(1), 35-46

Glossary at Cochrane Collaboration . http://www.cochrane.o 
3.rg/glossary/

Greenacre, M., 1998. Visualization of Categorical Data, San Diego, USA, 107-112.

Haque, M.M., Alam, M.R., Alam, M.M., Basak B., Sumi, K.R., Belton, B., Murshed-E-Jahan, K.,2015. Integrated floating cage aquageoponics system (IFCAS): An innovation in fish and vegetable production for shaded ponds in Bangladesh. Aquaculture Reports 2, 1-9. Available online at www.sciencedirect.com.

Hill, H., Hadarits, M., Rieger, R., Strickert, G., Davies, E.G.R., Strobbe, K.M., 2014. The Invitational Drought Tournament: What is it and why is it a useful tool for drought preparedness and adaptation? Weather and Climate Extremes. 3, 107-116. Available online at www. sciencedirect.com.

Islam, R., Reeder, R., 2014. No-till and conservation agriculture in the United States: An example from the David Brandt farm, Carroll, Ohio. International Soil and Water Conservation Research. 2(1), 97-107. Available online at www.sciencedirect.com.

Kanama, D., Nakazawa, N., 2017. The effects of ingredient branding in the food industry: case studies on successful ingredient-branded foods in Japan. Journal of Ethnic Foods 4, 126-131. Available online at www.sciencedirect. com.

Khan, M.H., 2011. Integrated Livestock-Fish Production Models for Livelihood Security in North-eastern India. International Journal of Bio-resource and Stress Management. 2(3), 377-381. Available online at www. pphouse.org

Knuth, U., Amjath-Babu, T.S., Knierim, A., 2018. Adoption of Farm Management Systems for Cross Compliance - An empirical case in Germany. Journal of Environmental Management 220, 109-117. Available online at www. sciencedirect.com.

Liberati, A., Altman, D.G., Tetzlaff, J., Mulrow, C., Gøtzsche, P.C., Ioannidis, J.P.A., Clarke, M., Devereaux, P.J., Kleijnen, J., Moher, D., 2009. The PRISMA Statement for Reporting Systematic Reviews and Meta-Analyses of Studies That Evaluate Health Care Interventions: Explanation and Elaboration. PLOS Medicine 6(7). https://doi.org/10.1371/journal.pmed.1000100.

Masseroni, D., Moller, P., Tyrell, R., Romani, M., Lasagna, A., Sali, G., Facchi, A., Gandolfi, C., 2018. Evaluating performances of the first automatic system for paddy irrigation in Europe. Agricultural Water Management 201, 58-69. Available online at www.sciencedirect.com.

Maiti, R., 2012. A Novel Strategy to Improve Crop Productivity under Sustainable Agriculture. International Journal of Bio-resource and Stress Management 3(2), 128-138. Available online at www.pphouse.org

Mchunu, N., Lagerwall, G., Senzanje, A., 2018. Aquaponics in South Africa: Results of a national survey. Aquaculture Reports 12, 12-19. Available online at www. sciencedirect.com.

Mendes, M., 2002. Coklu Uyum Analizi Tekniginin Kullanimi,(The Usage of Multiple Correspondence Analysis) Ziraat Muhendisleri Birligi Dergisi 33, 32-35.

Murage, A.W., Pittchar, J.O., Midega, C.A.O., Onyango, C.O., Khan, Z.R., 2015.Gender specific perceptions and adoption of the climate-smart push-pull technology in eastern Africa. Crop Protection 76, 83-91. Available online at www.sciencedirect.com.

Oana, C.O.C.A., 2017. The evaluation of Innovation in Agriculture. A Meta-Analytical study of literature. Scientific Papers Series Management, Economic Engineering in Agriculture and Rural Development. 17(1), 111-120.

Pasgaard, M., Strange, N., 2013. A quantitative analysis of the causes of the global climate change research distribution. Global Environment Change 23, 1684-1693.

Pawar, C.S., 2010. Steering Agriculture through the Concept of Triple S: Seed, Soil and Sustainability. International Journal of Bioresource and Stress Management 1(2), 113-114. Available online at www.pphouse.org

Phondani, P.C., Bhatt, I.D., Negi, V.S., Kothyari, B.P., Bhatt, A., Maikhuri, R.K., 2016. Promoting medicinal plants cultivation as a tool for biodiversity conservation and livelihood enhancement in Indian Himalaya. Journal of Asia-Pacific Biodiversity 9, 39-46. Available online at www.sciencedirect.com.

Putri, D.L., Annisa, M., Ningrum, L.P., Mursid, M., Amiadji, Murdjito, 2015. Agro Industrial Cluster Development Strategy Coastal Region District Banyuwangi. Procedia Earth and Planetary Science. 14, 136-143.

Ramchandani, R.A., Karmarkar, P., 2014. Sustainable rural livelihood security in the backward Districts of Maharashtra. Procedia- Social and Behavioral Sciences. 133, 265-278. Available online at www.sciencedirect. com.

Report of the Committee on Doubling Farmers' Income, 2017. Volume XI."Empowering the Farmers through Extension and Knowledge Dissemination". Department of Agriculture, Cooperation and Farmers' Welfare, Ministry of Agriculture \& Farmers' Welfare.

Rogers, E.M., 1962. Diffusion of Innovations. New York. The Free Press of Glencoe.

Rose, D.C., Morris, C., Lobley, M., Winter, M., Sutherland, W.J., Dicks L.V., 2018. Exploring the spatialities of technological and user re-scripting: The case of decision support tools in UK agriculture. Geoforum 89, 11-18.

Samiee, S., Rezaei-Moghaddam, K., 2017. The proposed alternative model to predict adoption of innovations: The case of no-till technology in Iran. Journal of the Saudi Society of Agricultural Sciences 16, 270-279. Available online at www.sciencedirect.com.

Sixt, G.N., Klerkx, L., Griffin, T.S., 2018. Transitions in water harvesting practices in Jordan's rainfed agricultural 
systems: Systemic problems and blocking mechanisms in an emerging technological innovation system. Environmental Science and Policy 84, 235-249. Available online at www.sciencedirect.com.

Solh, M., Ginkel, M.V., 2014. Drought preparedness and drought mitigation in the developing world's drylands. Weather and Climate Extremes. 3, 62-66. Available online at www.sciencedirect.com.

The Helgi Library, 2014. Arable Land Area. https://www. helgilibrary.com/indicators/arable-land-area . Retrieved on 18.09.2018

The PRISMA statement (http://www.prisma-statement.org) Toop, T.A., Ward, S., Oldfield, T., Hull, M., Kirby, M.E., Theodorou, M.K., 2017. AgroCycle-developing a circular economy in agriculture. Energy Procedia 123, 76-80. Available online at www.sciencedirect.com.

Vahid, I., Karem, C., Caroline, T., Martin F., Rainvill, E., Hardy, G., 2015. Micrometeorological Observations for the Evaluation of the Selective Inverted Sink against Radiation Frost and the Potential of a New Hybrid System. Procedia Earth and Planetary Science 15, 920-927. Available online at www.sciencedirect.com.

Zhang, C., Yan, J., 2014. Business Model Innovation on the Photovoltaic Water Pumping Systems for Grassland and Farmland Conservation in China. Energy Procedia 61, 1483-1486. Available online at www.sciencedirect.com. 